\title{
Reactivation of latent bovine herpesvirus type 5 in cattle with polioencephalomalacia induced by ammonium sulphate ${ }^{1}$
}

\author{
Nadia David ${ }^{2}$, Sílvia O. Hübner ${ }^{2}$, Franklin Riet-Correa ${ }^{3 *}$, Danisa Halfen ${ }^{4}$ and \\ Ricardo A. Lemos 5
}

\begin{abstract}
David N., Hubner S.O., Riet-Correa F., Halfen D. \& Lemos R.A. 2007. Reactivation of latent bovine herpesvirus type 5 in cattle with polioencephalomalacia induced by ammonium sulphate. Pesquisa Veterinária Brasileira 27(10):435-441. Hospital Veterinário, CSTR, Universidade Federal de Campina Grande, Campus de Patos, 58700-000 Patos, PB, Brazil. Email: franklin.riet@pesquisador.cnpq.br

In the state Mato Grosso do Sul, Brazil, outbreaks of meningoencephalitis by BoHV-5 and polioencephalomalacia (PEM) display similar epidemiological features, suggesting that meningoencephalitis may be associated with reactivation of a latent BoHV-5 infection, during the development of PEM. To test this hypothesis, four 7-8 months old steers negative for BoHV-5 antibodies were inoculated intranasally with BoHV-5 and received amprolium from day 35 to day 105 after inoculation. Because PEM was not produced during this period, ammonium sulphate was given from day 114 to day 180 after inoculation. Two uninfected control steers received amprolium and ammonium sulphate for the same periods. All inoculated cattle developed antibodies against BoHV-5 after inoculation and the virus was isolated from nasal swabs, indicating that they were infected. Two inoculated steers had clinical signs of PEM after 118 and 146 days after virus inoculation. One was euthanized after a clinical manifestation period of seven days and had severe lesions of PEM and meningoencephalitis. BoHV- 5 was isolated from the central nervous system of this animal. The other animal recovered but continued to manifest chronic signs of PEM and was euthanatized. On histological examination, the cerebral cortex, caudate nucleus and thalamus had multifocal areas of malacia and mild meningoencephalitis of the cortex. BoHV-5 was not isolated from the brain. One uninfected control steer had signs of neurological disease on day 158 and had lesions of PEM without meningoencephalitis at necropsy. The simultaneous production of PEM and diffuse meningoencephalitis, with isolation of BoHV-5, in one steer treated with ammonium sulphate, 118 days after BoHV-5 inoculation, suggests that latent BoHV-5 was reactivated in this animal submitted to experimental induction of PEM.
\end{abstract}

INDEX TERMS: Polioencephalomalacia, bovine herpesvirus type 5, viral reactivation, cattle.

\footnotetext{
${ }^{1}$ Received on August 29, 2006.

Accepted for publication on June 25, 2007.

Part of the MSc Dissertation of the first author in the Animal Health Program of the Veterinary College, Federal University of Pelotas, Rio Grande do Sul, Brazil.

${ }^{2}$ Faculdade de Veterinária, Universidade Federal de Pelotas, 96010-900 Pelotas, RS, Brazil.

${ }^{3}$ Hospital Veterinário, CSTR, Universidade Federal de Campina Grande, Patos, PB 58700-000, Brazil. "Corresponding author: franklin.riet@pesquisador.cnpq.br

${ }^{4}$ Depto Ciências Biomédicas, Universidade de Caxias do Sul, Campus Universitário, Cx. Postal 1352, Caxias do Sul, RS 95001-970, Brazil.

${ }^{5}$ Faculdade de Veterinária, Universidade Federal de Mato Grosso do Sul, Av. Senador Filinto Müller 2443. Cx. Postal 549, Campo Grande, MS 79070900, Brazil.
}

RESUMO.- [Reativação de herpesvírus bovino tipo 5 latente em bovinos com polioencefalomalacia induzida por sulfato de amônia.] No Mato Grosso do Sul surtos de meningoencefalite por herpesvírus bovino-5 (BoHV-5) e polioencefalomalacia (PEM) apresentam características epidemiológicas semelhantes, $o$ que sugere que a meningoencefalite pode estar associada com a reativação de uma infecção latente por BoHV-5 em animais com PEM. Para testar esta hipótese, 4 garrotes de 7-8 meses de idade, sem anticorpos séricos para BoHV-5 foram inoculados intranasal com BoHV-5 e receberam amprólio desde o dia 35 até o dia 105 após inoculação. Como não foi reproduzida PEM durante este período, os animais receberam sulfato de amônia desde o dia 114 até o dia 
180 após inoculação. Dois bovinos controles, não inoculados, receberam amprólio e sulfato de amônia durante os mesmos períodos. Todos os bovinos inoculados apresentaram anticorpos contra BoHV-5 após a inoculação e o vírus foi isolado de suabes nasais, indicando que foram infectados. Dois bovinos inoculados tiveram sinais clínicos de PEM após 118 e 146 dias da inoculação de vírus. Um que foi eutanasiado após um curso clínico de 7 dias apresentou lesões severas de PEM e meningoencefalite. BoHV-5 foi isolado do sistema nervoso central. $\mathrm{O}$ outro se recuperou, mas continuou a apresentar sinais crônicos de PEM. No exame histológico o córtex cerebral, núcleo caudato e tálamo apresentavam áreas multifocais de malacia e no córtex havia moderada meningoencefalite. BoHV-5 não foi isolado do encéfalo. Um garrote controle, não inoculado, apresentou sinais nervosos aos 158 dias após inoculação e na necropsia apresentava lesões de PEM, mas sem meningoencefalite. A reprodução simultânea de PEM e encefalite difusa em um animal tratado com sulfato de amônia, 118 dias após a inoculação de BoHV-5 e o re-isolamento do vírus do animal infectado sugere que a infecção latente por BoHV-5 foi reativada no animal submetido a indução experimental de PEM.

INDEX TERMS: Polioencefalomalacia, herpesvírus bovino tipo 5, reativação viral, bovinos.

\section{INTRODUCTION}

In Brazil, poliencephalomalacia (PEM) is a disease of cattle with epidemiology, clinical signs, and some microscopic lesions similar to those observed in meningoencephalitis caused by bovine herpesvirus type 5 (BoHV-5). PEM is frequent in the central-western (Nakazato et al. 2000, Lemos 2005) and southeastern regions of Brazil (Ferreira et al. 1986, Moro et al. 1994, Gonçalves et al. 2001) and had been reported also from southern Brazil (Santos et al. 1983). Meningoencephalitis by BoHV-5 is frequent in the southern (Méndez et al. 1987, Riet-Correa et al. 1989, Weiblen et al. 1989, Schild et al. 1994, Riet-Correa \& Schild 1995, Sanches et al. 2000, Elias et al. 2004, Rissi et al. 2006) and midwestern (Salvador et al. 1998, Colodel et al. 2002, Lemos 2005) regions. The disease had also been reported in the southeastern (Gomes et al. 2002) and northern (Riet- Correa et al. 2006) regions. BoHV-5 encephalitis is also common in Argentina where the disease had been frequently misdiagnosed as PEM (Carrillo et al. 1983, Perez et al. 2003).

In the state of Rio Grande do Sul, southern Brazil, BoHV-5 encephalitis represents $2.87 \%$ of all cases of cattle diseases diagnosed in a particular diagnostic laboratory from 1978 to 2004 (Elias et al. 2004). The disease occurred in 14 to 90 days old calves (Riet-Correa et al. 1989, Weiblen et al. 1989, Elias et al. 2004, Rissi et al 2006), and in cattle 7 to 30 months old (Méndez et al. 1987, Schild et al. 1994, Riet-Correa \& Schild 1995, Sanches et al. 2000, Elias et al. 2004, Rissi et al. 2006). In midwestern Brazil, PEM and meningoencephalitis by BoHV-5 represent $5 \%$ and $2 \%$, respectively, of all cattle submissions at a diagnostic laboratory between 2000 and 2004 (Lemos 2005). There, these two diseases have some similar epidemiological characteristics. Both have similar geographic distribution, and occur sporadically or in outbreaks with low morbidity, varying from $0.05 \%$ to $22 \%$ in the infections by BoHV-5, and from $0.02 \%$ to $14 \%$ in PEM. Both diseases affect grazing cattle bred extensively, and do not show any particular seasonal distribution. In addition, the age of affected cattle is similar, varying from 2 months to 6 years in BoHV-5 infections, and from 4 months to 7 years in PEM (Salvador et al. 1998, Nakasato et al. 2000, Colodel et al. 2002, Lemos 2005). Taking into account these similarities it is possible that both diseases are related and that some cases of BoHV-5 may be due to reactivation of latent BoHV-5 infections in cattle affected by PEM.

PEM can be naturally induced by a number of causes including sulfur, sodium chloride and lead intoxications and by alterations in thiamine metabolism as well. Experimentally, PEM can be induced by sulphur or amprolium administration (Gould et al. 1991, McAllister et al. 1992, Tanwar et al. 1993, Low et al. 1996, Wernery et al. 1998).

The present article reports the results of an experiment carried out to investigate whether BoHV-5 latent infection in cattle could be reactivated by experimentally induced PEM.

\section{MATERIALS AND METHODS}

Six 7-8 months old male crossbred steers (\# 1 to 6) devoid of neutralizing antibodies to BoHV-5 were used for the experimental studies. Legal and ethical national requirements were followed in the animal experiments. During the first 15 days, the animals were grazed in a native pasture and supplemented with food concentrate from a commercial supplier (Purina $\left.{ }^{\circledR}\right)$. After this period, steers were maintained indoors, in separate pens, receiving hay ad libitum and concentrate food at a proportion of $2 \%$ of the live weight for the first week, and subsequently increased to $2.5 \%$ of the live weight. After the adaptation period, steers $1,2,3$ and 5 were inoculated intranasally with BoHV-5 strain RP, originally isolated from a meningoencephalitis outbreak in southern Brazil (Souza et al. 2002). The virus was amplified in Madin-Darby bovine kidney cells (MDBK). Steers were inoculated with $10 \mathrm{~mL}$ ( $5 \mathrm{~mL}$ per nostril) of a virus suspension with $5 \times 10^{7,6} \mathrm{TCID}_{50}$ of the virus. Two steers (4 and 6) were inoculated with sterile cell culture medium and maintained as uninfected controls. The steers were observed daily for clinical signs during the experimental period.

Nasal swabs were collected on days 7 and 14 post-inoculation (pi). Swabs were then eluted in $3 \mathrm{~mL}$ of MEM, and supplemented with $200 \mathrm{U} / \mathrm{mL}$ penicillin, $200 \mu \mathrm{g} / \mathrm{mL}$ streptomycin and $5 \mu \mathrm{g} / \mathrm{mL}$ amphotericin B for 1 hour at room temperature. Volumes of $200 \mathrm{~mL}$ of each supernatant were used to inoculate MDBK monolayers. Infected cultures were observed for the presence of cytopathic effects (CPE) for 5 days. All negative cultures were frozen at $-70^{\circ} \mathrm{C}$ and reinoculated on fresh MDBK monolayers to investigate the presence of infectious virus. Identification of BoHV-5 infected cells was performed by immunofluorescence (IFA) and virus-neutralization (VN).

Neutralizing antibody to BoHV-5 infection were evaluated by virus neutralization (VN) on serum samples collected on days 0 and 29 post infection (dpi) and on the day of euthanasia. VN was performed by the constant virus-variable serum method as described by Deregt et al. (1993), with $100 \mathrm{TCID}_{50}$ of virus (BoHV-5 strain RP) against twofold serum dilutions. Antibody titres were expressed as the reciprocal of the end point dilution.

To induce PEM, amprolium (Amprolbase ${ }^{\circledR}$, amprolium 40\%, Farmabase Saúde Animal Ltda, Campinas, São Paulo) and subse- 
quently sodium sulphate were administered as follows: from day 34 to day $77 \mathrm{pi}$, all steers received $440 \mathrm{mg}$ of amprolium per $\mathrm{kg}$ of body weight, mixed in the food. From day 77 to day 105, the daily amount of amprolium was increased to $600 \mathrm{mg} / \mathrm{kg}$ bw. From day 106 to day 113 after inoculation the animals received food without amprolium. From day 114 to day $180,3 \%$ of ammonium sulphate was added to the food. From day 143 until the end of the experiment, the animals received the concentrated food ad libitum and hay was no longer administered.

Steers 2 and 4, that displayed clinical signs, were euthanized in extremis and necropsied on days 125 and 160 pi, respectively. Steer 3 displayed signs of chronic poisoning and was euthanized and necropsied at the end of the experiment (180 dpi). Steers without clinical signs (1, 5 and 6$)$ were slaughtered at the end of the experiment (180 dpi). Fragments of CNS tissues (frontal cortex and cerebellum) were homogenized to $20 \%$ (W/V) with MEM supplemented with antibiotics and clarified at $2,500 \times$ g for $20 \mathrm{~min}$ at $4^{\circ} \mathrm{C}$. Supernatants were used for virus isolation as described above.

For histological examination of the CNS of the animals that displayed clinical signs, the whole nervous system, except the fragments used for virus isolation, and samples from different tissues were fixed in $10 \%$ buffered formalin. Histologic evaluation of the CNS was performed in transverse sections taken from the cervical, thoracic and lumbar spinal cord, medulla, pons, cerebellar peduncles and cerebellum, rostral and caudal colliculi, thalamus and hypothalamus, basal nuclei, geniculate body, and frontal, temporal, parietal and occipital cortex. All tissues were embedded in paraffin, sectioned at $6 \mu \mathrm{m}$, and stained by hematoxylin-eosin.

\section{RESULTS}

Four days after beginning ingestion of ammonium sulphate Steer 2, which had been inoculated with BoHV-5 at the start of the experiment (118 days before), showed loss of appetite. Seven days later, this animal developed acute nervous signs characterized by deep depression followed by lateral recumbence and opisthotonous and was euthanized. BoHV-5 was isolated from nasal swabs obtained 7 and 14 dpi and from tissues samples of frontal cortex and cerebellum collected at necropsy. At necropsy, subdural hemorrhages were found at the level of the first and second cervical vertebrae. The cerebellum was herniated trough the foramen magnum, and a hemorrhagic area with a diameter of approximately $2 \mathrm{~cm}$ (Fig.1) was observed in the thalamus, hypothalamus, third ventricle and caudal region of the internal capsule. Histologically, encephalitis with severe perivascular cuffing of mainly mononuclear cells and focal gliosis were observed involving the cerebral cortex (Fig.2). Numerous eosinophilic neurons appeared in these cortical areas. Diffuse meningitis with infiltration of monocuclear cells was also observed. The parietal cortex showed multifocal areas of malacia characterized by diffusely pale neuropil or laminar necrosis with vacuolation of the neuropil. Endothelial hyperplasia was observed in the blood vessels. The caudate nucleus and putamen had focal areas of malacia with vacuolization of the neuropil, eosinophilic neurons, and mild proliferation of the blood vessels endothelium. In the thalamus and geniculte body, a severe hemorrhagic area surrounded by areas of malacia with vacuolization of the neuropil, neuronal necrosis and edema was observed. Glial cells were picnotic and

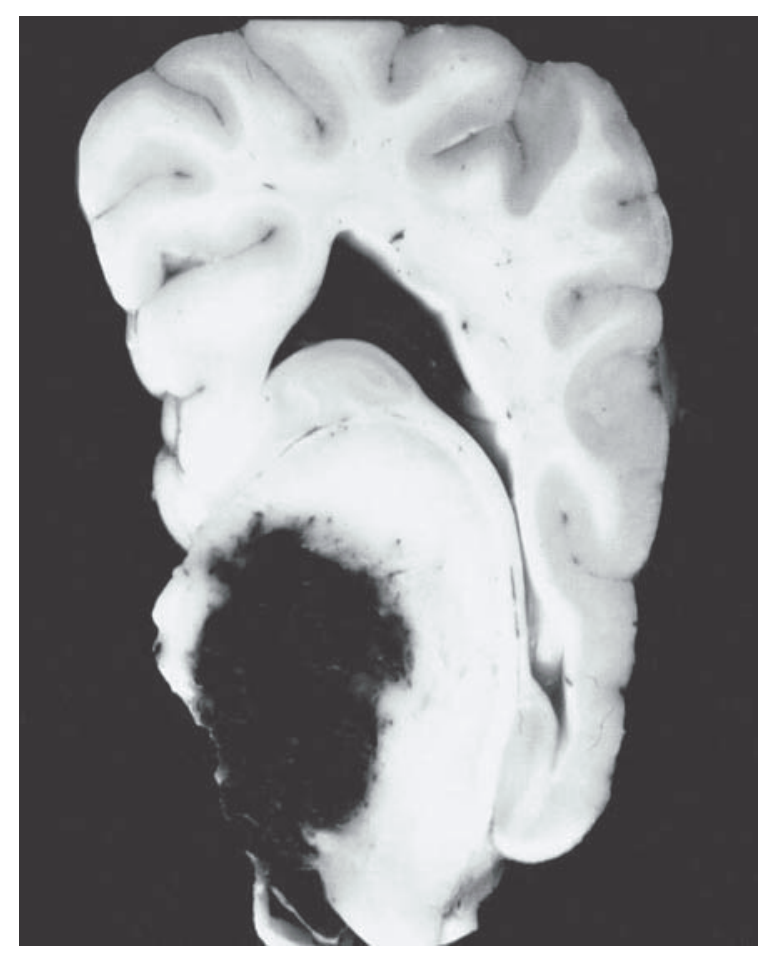

Fig.1. Severe hemorrhage is observed in the thalamus (Steer 2).

numerous astrocytes had a clear cytoplasm. Many blood vessels were degenerated showing an eosinophilic wall infiltrated by neutrophiles and mononuclear cells with vacuolization of the neuropil around the vessel (Fig.3). Hemorrhages and edema were observed at the periphery of those blood vessels. No inflammatory lesions were observed in the basal nuclei, geniculate body and thalamus. Perivascular cuffing of mononuclear cells were observed in some blood vessels in the rostral and caudal culliculi (Fig.4). A focal area of malacia with vacuolization of the neuropil and focal gliosis were observed on the rostral colliculi. Mild perivascular cuffing was observed on the medulla and subdural hemorrhages were present on the cervical spinal cord. BoHV-5 specific neutralizing antibodies (titre of 16) were detected in sera collected on days 29 and 125 pi.

After receiving ammonium sulphate for 32 days, Steer 3 , which had also been inoculated with BoHV-5 at the start of the experiment, developed mild bloat and an oral ammonium sulphate smell. The bloat persisted for 18 days. After 50 days of ammonium sulphate administration, the animal became excited, showing uncoordinated gait and head pressing against the wall. Later, it developed nasal and ocular mucopurulent discharges, depression and blindness, remaining mostly in recumbence, with anorexia and reduced water consumption. These clinical signs persisted for four days when partial recovery apparently took place, but the steer remained blind and depressed. Sixty six days after the beginning of the ammonium sulphate administration (180 dpi) this steer was euthanized. At necropsy an area of cavitation of approximately $0.7 \mathrm{~cm}$ in diameter was observed on the thalamus. BoHV-5 was not isolated from the CNS. On histological examination the Pesq. Vet. Bras. 27(10):435-441, outubro 2007 

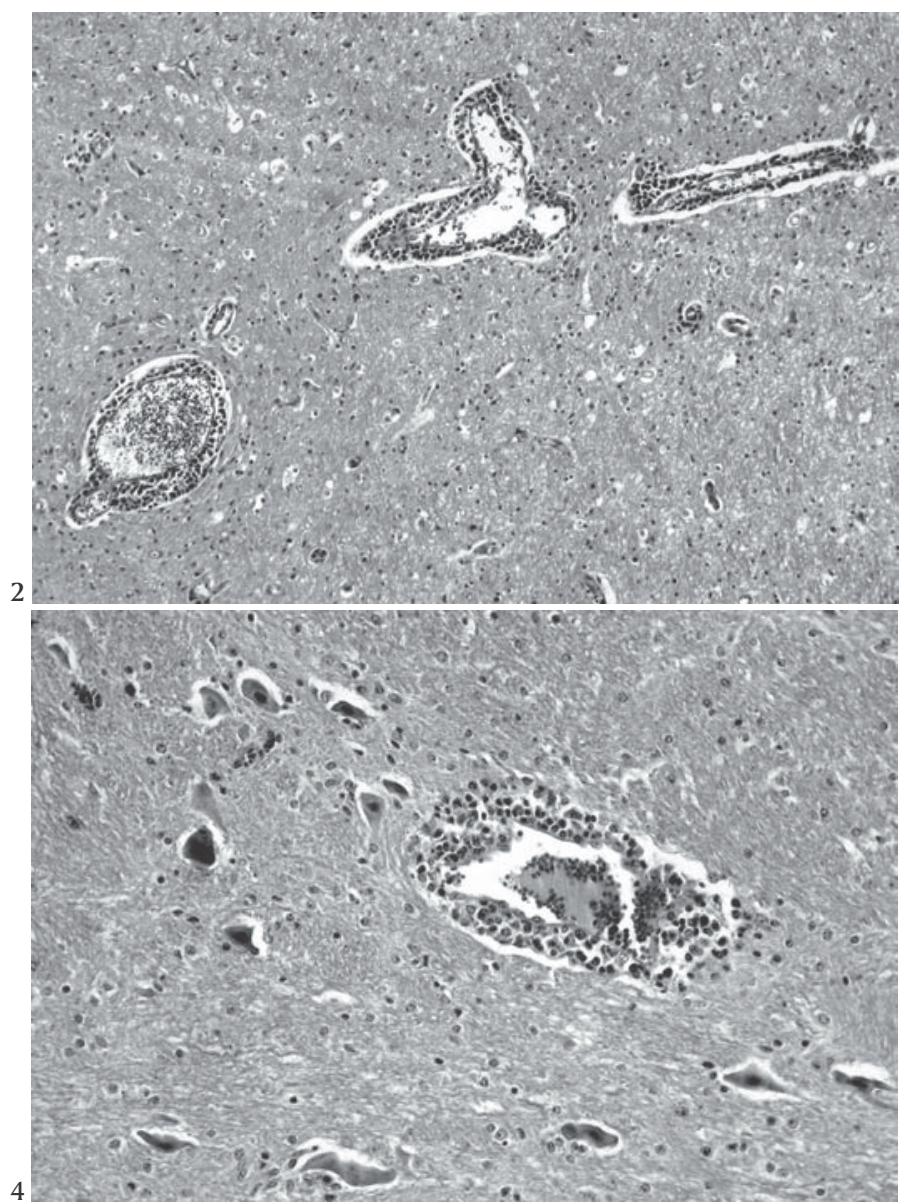

Fig.2. Cerebral cortex showing severe perivascular cuffing of mainly mononuclear cells, and vacuolization of the neuropil (Steer 2). H-E, obj.10x.

Fig.4. Caudal coliculli showing perivascular cuffing of mononuclear cells (Steer 2). H-E, obj.10x.

cerebral cortex had multifocal areas of malacia characterized by acidophilic neurons and pale neuropil. In some areas the blood vessels showed endothelial hyperplasia. Infiltration by mononuclear cells was observed on the meninges. In the frontal cortex, perivascular cuffing of mainly lymphocytes were observed, but in the temporal and occipital cortex mainly macrophages were observed on the perivascular cuffing. Areas of cavitations full of macrophages were observed on the caudate nucleus and thalamus (Fig.5). On the thalamus mononuclear cells were observed around the cavitations. The geniculate body presented some areas of malacia with severe blood vessels proliferation, axonal spheroids and acidophilic neurons. Small areas of malacia were observed on the caudal culliculi. Multifocal focal areas of malacia were observed on the cerebellum affecting the whole grey substance, but sometimes extending to the white matter. Mild perivascular cuffing was observed in some blood vessels of the cortex, rostral and caudal culliculi, and medulla. Neutralizing antibody titres on days 0,29 and 180 pi were $<2,8$ and 32 , respectively. Virus shedding in nasal secretions was detected on days 7 and 14 pi.
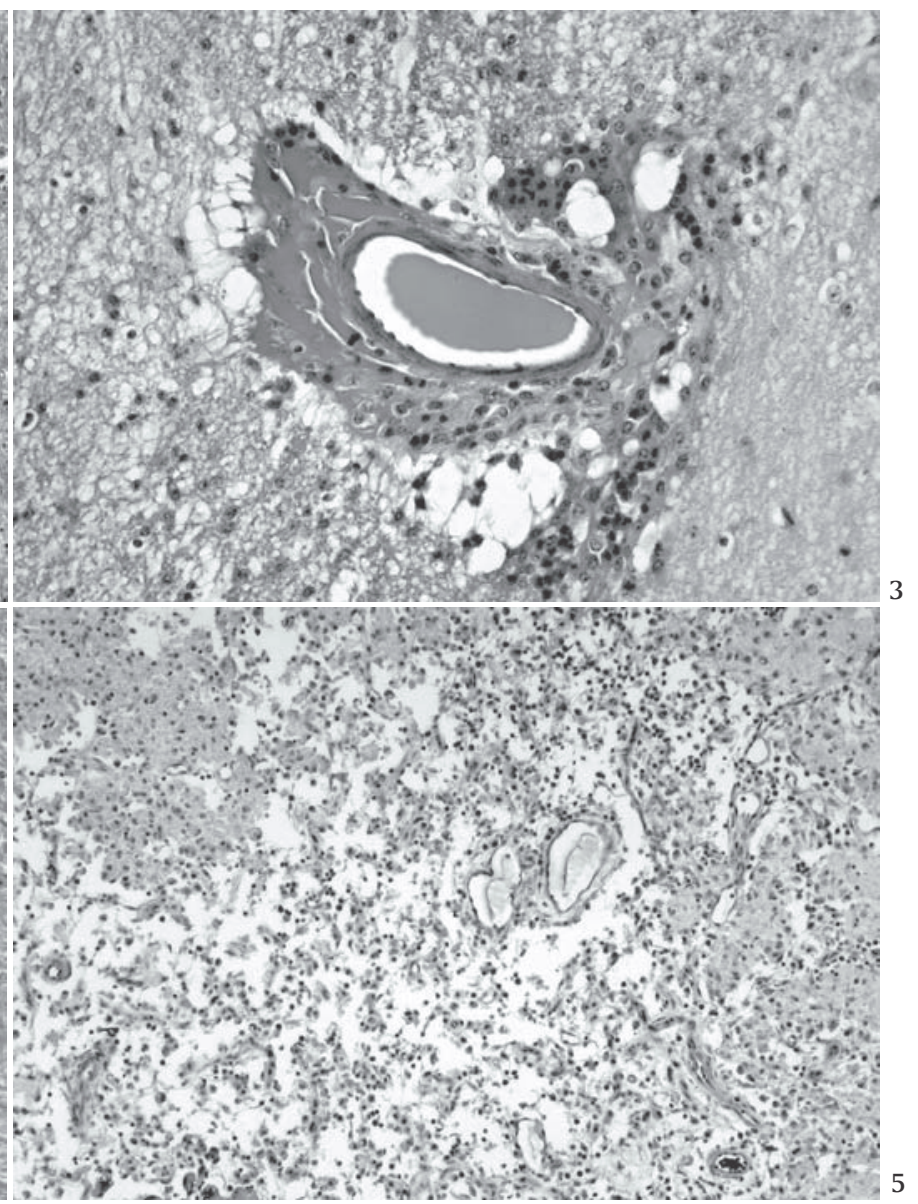

Fig.3. Caudate nucleus showing degenerated blood vessels with eosinophilic wall and surrounded by neutrophiles, mononuclear cells and edema. The neuropil around the vessel is vacuolated (Steer 2). H-E, obj.20x.

Fig.5.Thalamus showing a cavity filled with macrophages. H-E, obj.10x.

Steers 1 and 5, which were inoculated with BoHV-5 and received ammonium sulphate, presented no clinical signs. BoHV-5 was isolated from nasal swabs. Serum samples obtained from these animals contained neutralizing anti-bodies with titres of 8 on days 29 and 180 pi. Attempts to detect infectious virus from the CNS of steers culled on day $180 \mathrm{pi}$ were unsuccessful.

Steer 4 , which was not infected but received ammonium sulphate had decreased food consumption after 12 days of ammonium sulphate ingestion. After 44 days of ingestion presented nervous signs with depression and uncoordinated gait. On the next day was in lateral recumbence with opisthotonous and was euthanized 48 hours after the first nervous signs. At necropsy a hemorrhagic area with a diameter of approximately $2 \mathrm{~cm}$ was observed in the thalamus and third ventricle. The cerebellum was herniated through the foramen magnum. The liver had multifocal to coalescent areas of hemorrhages with a dark red color mixed with yellow areas. On the cut surface the red areas were more frequent on a subcapsular location, but were found in the whole surface. Histologically, the cerebral cortex had multifocal areas of 
malacia with pale or vacuolated neuropil, acidophilic neurons and increased perivascular spaces. The vascular endothelium was hyperplasic and some macrophages were found around the blood vessels. In some areas of the cortex the malacia affected all layers, but in others, mainly in the temporal and occipital cortex, had a laminar distribution affecting mainly the deep layers. Perivascular edema was observed occasionally on the subcortical white matter. Similar focal areas of malacia were observed in the caudate nucleus and putamen. Macrophages were observed around the blood vessels. Areas of malacia with vacuolization of the neuropil were observed on the internal and external capsule and subcortical white matter. Axonal spheroids were observed in the later. Severe hemorrhages were observed on the thalamus and geniculate body. Around the hemorrhagic area the neuropil was vacuolated. Edema, axonal spheroids and some eosinophilic neurons were also observed. Hyaline degeneration and infiltration by neutrophils and mononuclear cells were observed in the wall some blood vessels. Hemorrhages, edema and myelin degeneration were observed around some of these blood vessels. Degeneration in the wall of the blood vessels, perivascular edema and hemorrhages, and vacuolization and edema of the neuropil were also observed on the rostral and caudal culliculi. Numerous eosinophilic neurons were observed on the central grey matter. Multifocal hemorrhages and vacuolated hepatocytes were observed in the liver. Neutralizing antibodies to BoHV-5 were not detected in this steer. Attempts to recover infectious virus from the CNS were negative.

Steer 6, which was not infected but received ammonium sulphate had no clinical signs of disease. BoHV-5 was not detected from nasal swabs or CNS tissues. Likewise, no neutralizing antibodies were found in the serum samples obtained from this animal.

\section{DISCUSSION}

In this experiment, one of the infected animals (Steer 2), inoculated with BoHV-5 on the first day of the experiment, showed clinical signs 118 days after inoculation, 4 days after starting the ingestion of ammonium sulphate. The severe encephalitis and lesions characteristics of PEM observed in this steer suggest that the BoHV-5 inoculated 180 days before was reactivated associated with the development of PEM. These findings suggest that, at least experimentally, BoHV-5 can be reactivated in cattle with develop PEM and this reactivation results in severe encephalitis and PEM. It is possible that this situation may also occur in natural outbreaks of BoHV-5 infections in Brazil, where both diseases display similar epidemiologic characteristics, and lesions of PEM in cerebral cortex, basal ganglia, thalamus, and colliculi are found in spontaneous cases of BoHV-5 infection (Elias et al. 2004, RietCorrea et al. 2006).

Herpesvirus reactivation occurs after administration of corticosteroids or elevated levels of natural corticosteroids as a consequence of stress (Engels \& Ackermann 1996). Experimentally, BoHV-5 reactivation can be efficiently induced by the administration of dexamethasone (Belknap et al. 1994, Silva et al. 1998, Perez et al. 2002, Vogel et al. 2003). Others situations, such as vaccination with attenuated vaccines, low blood levels of gammaglobulins, bronchopneumonia, and supurative nephritis have also been associated to reactivation of bovine herpesvirus (Furuoka et al. 1995). Virus replication in the course of reactivation may cause the development of disease, although clinical signs may not become apparent (Belknap et al. 1994).

The determination of the type and distribution of the lesions of malacia may be helpful to discriminate between encephalitis due BoHV-5 acute infection and encephalitis due to BoHV-5 reactivation associated with PEM. Malacia of the cerebral cortex with presence of guitter cells is frequently observed in spontaneous cases of BoHV-5 infections in Brazil, Uruguay and Argentina (Carrillo et al. 1983, Riet-Correa et al. 1989, Schild et al. 1994, Riet-Correa \& Schild 1995, Rivero et al. 1997, Salvador et al. 1998, Sanches et al. 2000, Colodel et al. 2002, Perez et al. 2003, Elias et al. 2004, Riet-Correa et al. 2006, Rissi et al. 2006). In reports from other countries, malacia is absent (Johnston et al. 1962, Barenfus et al. 1963, Gardiner et al. 1964, Bartha et al. 1969, Bagust \& Clark 1972, Gough \& James 1975, Watt et al. 1981, D’offay et al. 1993) or rarely reported (Eugster et al. 1974, Hill et al. 1984, Furuoka et al. 1995, Ely et al. 1996). Malacia of the cerebral cortex had also been reproduced in cattle inoculated with BoHV-5 (Hall et al. 1966, David 2002, Blanco et al. 2003, Silva et al. 2006), but in most experimental reproduction of the disease this lesion is not reported (Johnston et al. 1962, Bagust \& Clark 1972, Eugster et al. 1974, Belknap et al. 1994, Perez et al. 2002, Hubner et al. 2005). Nevertheless, some of these authors mentioned neuronal degeneration and necrosis (Johnston et al. 1962, Perez et al. 2002, Hubner et al. 2005) or the presence of focal rarefaction necrosis (Bagust \& Clark 1972).

Deep lesions of malacia, mainly in basal nuclei, thalamus, rostral and caudal colliculi are observed in spontaneous and experimental cases of PEM (Tanwar et al. 1993, Low et al. 1996, Loneragan et al. 1998). In BoHV-5 meningoencephalitis, malacia of the basal nuclei, thalamus and mesencephalon, not mentioned in most reports of spontaneous or experimental infections, could be due to the reactivation of the virus in animals previously affected by PEM. The results of the present experiment support this hypothesis. Salvador et al. (1998) reported 15 outbreaks of BoHV-5 neurological disease in the state of Mato Grosso do Sul. Mild infiltration by macrophages in the basal nuclei, thalamus, mesencephalon, pons, cerebellum, medulla and cervical spinal cord were observed in some cases. Malacia of the basal nuclei was also reported in Argentina, in a retrospective study of cases on BoHV-5 encephalitis, which had been previously diagnosed as PEM (Perez et al. 2003). More recently, lesions of malacia of the basal nuclei, mesencephalon, and thalamus were reported in spontaneous outbreaks of BoHV-5 infections in the Brazilian states of Rio Grande do Sul (Elias et al. 2004) and Pará (RietCorrea et al. 2006). More studies are necessary to determine if only cases of BoHV-5 infections due to reactivation of the virus in cattle with PEM had deep lesions of malacia.

One fact observed in some of the recent outbreaks of BoHV5 infection in Mato Grosso do Sul was that farmers reported 
that in some outbreaks the first affected cattle respond to thiamin treatment, but the treatment was not efficient in the subsequent cases, which after histologic examination confirmed to be caused by BoHV-5. It is possible that the first affected animals had PEM, with the reactivation of the virus in one or more PEM affected cattle, and probably followed by the transmission of the virus to other cattle. More detailed studies of outbreaks of BoHV-5 infections and PEM will be necessary to demonstrate the possible association between these two diseases, mainly in Brazil and Argentina, where there is a high incidence of both. Another possible explanation of the high frequency of lesions of malacia in cases of BoHV-5 infections in Brazil and Argentina, when compared with other countries, is the difference in pathogenicity of BoHV-5 isolates, with some isolates being able to cause deep lesions of malacia.

Steer 3, which was infected by BoHV-5, showed clinical signs after ingesting ammonium sulphate for 32 days. It underwent partial recovery, however it remained with sequelae. At necropsy chronic PEM lesions, with mild lesions of encephalitis were observed in the cortex, rostral and caudal culliculi, and medulla. The sequelae were probably due to PEM lesions, but the mild inflammatory lesions may have been caused by BoHV-5 reactivation. BoHV-5 was not isolated from the brain, nevertheless, the significant increase of the neutralizing antibody titres observed suggest that the virus was reactivated. In addition, the isolation of BoHV-5 in cell cultures in other cases of BoHV-5 infections had limited success (Perez et al. 2002, 2003, Silva et al. 2006).

Deep lesions of malacia in basal nuclei, geniculate body, and coliculli were observed in the three steers (2, 3 and 4$)$ with PEM. Malacia of the geniculate body was observed in Steer 2 and 3, and of the cerebellum in Steer 3. The presence of deep lesions of malacia has been used to differentiate PEM caused by sulfur intoxication from PEM associated with alterations in thiamine metabolism (Low et al. 1996, Loneragan et al. 1998), but in experiments in cattle (David 2002) and buffaloes (Tanwar et al. 1993) deep lesions were also observed in amprolium induced PEM, suggesting that deep lesions can occur in PEM due to different causes.

In Steer 2, infected with BoHV-5, and in Steer 4, not infected, severe hemorrhages were observed, mainly in the thalamus, extending from the internal capsule to the mesencephalon. Similar lesions due to the vascular lesions caused by the ammonium sulphate had been reported in some cases of spontaneous sulfur intoxication in sheep (Hamlen et al. 1993) and cattle (Loneragan et al. 1988). Severe hemorrhages were also observed in the liver of Steer 4, similar to those observed in the liver of sheep intoxicated by $\mathrm{H}_{2} \mathrm{~S}$ (McAllister et al. 1992). Hemorrhages of the CNS due to degenerative lesions of the blood vessels had been reported in cases of sulfur intoxication with acute clinical signs and a rapid clinical manifestation period (Hamlen et al. 1993, Loneragan et al. 1998). Lesions of malacia observed in the cerebellum of Steer 3 were probably due to the herniation of the cerebellum through the foramen magnum, caused by cerebral edema. Malacia of the cerebellum was reported in spontaneous infection by BoHV-5 in a heifer (Gough \& James 1975).
In these experiments, the administration of amprolium failed to reproduce PEM, and in the attempts to reproduce the disease with ammonium sulphate, only 3 out of 6 animals were affected. In previous experiments in similar conditions, PEM was reproduced in 3 out of 4 cattle after the ingestion of $440-660 \mathrm{mg} / \mathrm{kg}$ of amprolium daily for 20-56 days (David 2002). In other experiments, the administration of amprolium also failed to cause PEM in some of the treated animals (Loew et al. 1972, Lilja 1973), and in an experiment with dromedary camels PEM was induced in animals fed hay, but not in animals fed barley (Wernery et al. 1998), demonstrating the importance of the physiologic conditions of the fore stomachs in the production of PEM. Also, the ingestion of toxic amounts of sulfur failed to induce clinical signs of PEM in all animals exposed (Gould et al. 1991). Different reasons can be responsible for this failure: previous levels of sulphur in the diet; aspects associated with the production of $\mathrm{H}_{2} \mathrm{~S}$ by the ruminal flora; ruminal $\mathrm{pH}$, because an acid $\mathrm{pH}$ increases $\mathrm{H}_{2} \mathrm{~S}$ production; easy digestible polysaccharides and low fiber in the food, which also increase $\mathrm{H}_{2} \mathrm{~S}$ production; and amount of other minerals in the diet, including copper, which combine with sulfur forming thiosulphates (Gould et al. 1991).

\section{REFERENCES}

Bagust T.J. \& Clark I. 1972. Pathogenesis of meningoencephalitis produced in calves by infectious bovine rhinotracheitis herpesvirus. J. Comp. Pathol. 82:375-382.

Barenfus M., Delliquadri C.A., McIntyre R.W. \& Schroeder R.J. 1963. Isolation of infectious bovine rhinotracheitis virus from calves with meningoencephalitis. J. Am. Vet. Med. Assoc. 143:725-755.

Bartha A., Hadjdu G., Aldasy P. \& Paczolay G .1969. Occurrence of encephalitis caused by infectious bovine rhinotracheitis virus in calves in Hungary. Acta Vet. Hungarica 19:145-151.

Belknap E.B., Collins J.K., Ayers V.K. \& Schultheiss P.C. 1994. Experimental infection of neonatal calves with neurovirulent bovine herpesvirus type 1.3. Vet. Pathol. 31:358-365.

Blanco V.F.J., Carrillo B.J., Barrandeguy M.E., Pereira J.J., Fondevila N., Duffy S.J., Gavier D., Berra G., Bolondi A. \& Lager I.A. 2003. Patología y patogenia de la encefalitis por herpes virus. Reproducción experimental en terneros. Vet. Argent. 20:500-514.

Carrillo B. J., Pospischil A. \& Dahme E. 1983. Pathology of a bovine viral necrotizing encephalitis in Argentina. J. Vet. Med., Series A, 30:161-168.

Colodel M.E., Nakazato L., Weiblen R., Mello R.M., Silva R.P., Souza M.A., Oliveira J.A. \& Caron L. 2002. Meningoencefalite necrosante em bovinos causada por herpesvírus bovino no estado de Mato Grosso, Brasil. Ciência Rural, Santa Maria, 32:293-298.

Deregt D., Cho H.J. \& Kozub G.C. 1993. A comparative evaluation of two sensitive serum neutralization tests for bovine herpesvirus 1 antibodies. Can. J. Vet. Res. 57:56-59.

D’Offay J.M., Mock R.E. \& Fulton R.W. 1993. Isolation of characterization of encephalitic bovine herpesvirus type 1 isolates from cattle in North American. Am. J. Vet. Res. 54:534-538.

David N. 2002. Associação de meningoencefalite por herpesvírus bovino-5 com polioencefalomalácia. MSc Thesis, Faculdade de Veterinária, Universidade Federal de Pelotas, Brasil.

Elias F., Schild A.L. \& Riet-Correa F. 2004. Meningoencefalite e encefalomalacia por herpes vírus bovino-5: distribuição das lesões no sistema nervoso central de bovinos naturalmente infectados. Pesq. Vet. Bras. 24:123-131.

Ely R.W., D’offay J.M., Ruefer A.H. \& Cash C. 1996. Bovine herpesviral encephalitis: a retrospective study on archived formalin-fixed, paraffinembedded brain tissue. J. Vet. Diag. Invest. 8:487-492. 
Engels M. \& Ackermann M. 1996. Pathogenesis of ruminant herpesvirus infections. Vet. Microbiol. 53:3-15.

Eugster A.K., Angulo A.B. \& Jones L.P. 1974. Herpesvirus encephalitis in range calves. Proc. 17th Annu. Meet. Am. Assoc. Vet. Lab. Diagnost., p.267-281.

Ferreira F.A., Coelho H.E. \& Bastos J.E.D. 1986. Polioencefalomalácia em bovinos no estado de Minas Gerais. Arq. Bras. Med. Vet. Zootec. 38:693-700.

Furuoka H., Izumida N., Hariuchi M. \& Osame S. 1995. Bovine herpesvirus meningoencephalitis association with infectious bovine rhinotracheitis (IBR). Acta Neuropathol. 90:565-571.

Gardiner M.R., Nairn M.E. \& Sier A.M. 1964. Viral meningoencephalitis of calves in Western Australian. Aust. Vet. J. 40:225-228.

Gomes L.I., Rocha M.A., Costa E.A., Lobato Z.I.P., Mendes L.C.N., Borges A.S., Leite R.C. \& Barbosa-Stancioli E.F. 2002. Detecção de herpesvírus bovino 5 (BoHV-5) em bovinos do sudeste brasileiro. Arq. Bras. Med. Vet. Zootec. 54:217-220.

Gonçalves R.C., Viana L., Sequeira J.L., Bandarra E.P., Chiacchio S.B. \& Kuchembuck M.R.G. 2001. Aspectos clínicos, anatomopatológicos e epidemiológicos da polioencefalomalácia em bovinos, na região de Botucatu, SP. Veterinária Notícias, Uberlândia, 7:53-57.

Gough A. \& James D. 1975. Isolation of IBR virus from a heifer with meningoencephalitis. Can. Vet. J. 16:313-314.

Gould D.H., McAllister M.M., Savage J.C. \& Hamar D.W. 1991. High sulfide concentrations in rumen fluid associated with nutritionally induced polioencephalomalacia in calves. Am. J. Vet. Res. 52:1164-1169.

Hall W.T.K., Simmons G.C., French E.L., Snowdon W.A. \& Asdell M. 1966. The pathogenesis of encephalitis caused by the infectious bovine rhinotracheitis virus. Aust. Vet. J. 42:229-237.

Hamlen H., Clark E. \& Janzen E. 1993. Polioencephalomalacia in cattle consuming water with elevated sodium sulphate levels: a herd investigation. Can. Vet. J. 34:153-158.

Hill B.D., Hill M.W.M., Chung Y.S. \& Whittle R.J. 1984. Meningoencephalitis in calves due to bovine herpesvirus type 1 infection. Aust. Vet. J. 61:242243.

Hubner S.O., Oliveira A.P., Franco A.C., Esteves P.A., Silva A.D., Spilki F.R., Rijsewijk F.A.M. \& Roehe P.M. 2005. Experimental infection of calves with a gI, gE, US9 negative bovine herpesvirus type 5. Comp. Immun. Microbiol. Infect. Dis. 28(3):187-196.

Johnston L.A.Y., Simmons G.C. \& McGavin M.D. 1962. A viral meningoencephalitis in calves. Aust. Vet. J. 38:207-215.

Lemos R.A.A. 2005. Enfermidades do sistema nervoso de bovinos de corte das regiões centro-oeste e sudeste do Brasil. Tese de doutorado. Universidade Estadual Paulista, Jaboticabal, Brasil.

Lilja C.G. 1973. Cerebro-cortical necrosis (CCN) in a calf. Acta Vet. Scand. 14:464-473.

Loew F.M. \& Dunlop R.H. 1972. Induction of thiamine inadequacy and polioencephalomalacia in adult sheep with amprolium. Am. J. Vet. Res. 33:2195-2205.

Loneragan G.H., Gould D.H., Callan R.J., Sigurdson C.J. \& Hamar D.W. 1998. Association of excess sulfur intake and an increase in hidrogen sulfide concentrations in the ruminal gas cap of recently weaned beef calves with polioencephalomalacia. J. Am. Vet. Med. Assoc. 213:1599-1604.

Low J.C., Scott P.R., Howie E., Lewis M., Fitzsimons J. \& Spence J.A. 1996. Sulphur-induced polioencephalomalacia in lambs. Vet. Rec. 138:327-329.

McAllister M.M., Gould D.H. \& Hamar D.W. 1992. Sulphide-induced polioencephalomalacia in lambs. J. Comp. Pathol. 106:267-278.

Méndez M.C., Riet-Correa F., Schild A.L. \& Ferreira J.L.M. 1987. Doenças diagnosticadas no ano de 1986. Boletim do Laboratório Regional de Diagnóstico no.8, p.30.

Moro L., Nogueira R.H.G., Carvalho A.U. \& Marques D.C. 1994. Relato de três casos de polioencefalomalácia em bovinos. Arq. Bras. Med. Vet. Zootec. 46:409-416.

Nakazato L., Lemos R. \& Riet-Correa F. 2000. Polioencefalomalacia em bovi- nos nos estados de Mato Grosso do Sul e São Paulo. Pesq. Vet. Bras. 20:119125.

Perez S.E., Bretschneider M.R., Leunda M.R., Osório F.A., Flores E.F. \& Odeón A.C. 2002. Primary infection, latency, and reactivation of bovine herpesvirus type 5 in the bovine nervous system. Vet. Pathol. 39:437-444.

Perez S.E., Vagnozzi A., Sur J.H., Odriozola E., Campero C.M. \& Odeón A.C. 2003. Análisis retrospectivo de casos con diagnóstico de necrosis cerebrocortical y su relación con herpesvirus bovino tipo 5. Revta Argent. Microbiol. 35:69-73.

Riet-Correa F., Vidor T., Schild A.L. \& Méndez M.C. 1989. Meningoencefalite e necrose do córtex cerebral em bovinos causada por herpesvirus bovino. Pesq. Vet. Bras. 9:13-16.

Riet-Correa F. \& Schild A.L. 1995. Doenças diagnosticadas pelo Laboratório Regional de Diagnóstico no ano de 1994 e comentários sobre algumas doenças. Boletim do Laboratório Regional de Diagnóstico no.15, p.7-9.

Riet-Correa G., Duarte M.D., Barbosa J.D., Oliveira M.C.M., Cerqueira V.D., Brito M.F. \& Riet-Correa F. 2006. Meningoencefalite por Herpesvirus bovino-5 no Estado do Pará. Pesq. Vet. Bras. 26:44-46.

Rissi D.R, Oliveira E.N., Rech R.R., Pierezan F., Lemos R.A.R. \& Barros C.S.L. 2006. Epidemiologia, sinais clínicos e distribuição das lesões encefálicas em bovinos afetados por meningoencefalite por herpesvírus bovino-5. Pesq. Vet. Bras. 26(2):123-132.

Rivero R., Campo R., Gil J., Giannechini E., Mendaro A. \& Wettstein R. 1997. Meningoencefalitis por herpesvirus en bovinos y su comprobación mediante el procedimiento de hibridación de ácidos nucleicos (Dot Blot). Veterinária, Uruguay, 33:5-10.

Salvador S.C., Lemos R.A.A., Riet-Correa F., Roehe P.M. \& Osório A.L.A.R. 1998. Meningoencefalite em bovinos causada por herpesvirus bovino 5 no Mato Grosso do Sul e São Paulo. Pesq. Vet. Bras. 18:76-83.

Sanches A.W.D., Langohr I.M., Stigger A.L. \& Barros C.S.L. 2000. Doenças do sistema nervoso central em bovinos no sul do Brasil. Pesq. Vet. Bras. 20:113118.

Santos M.N., Jardim Filho J.O. \& Grando F.A. 1983. Polioencefalomalacia em bovinos no Rio Grande do Sul. Pesq. Vet. Bras. 3:37-39.

Schild A.L., Riet-Correa F. \& Pereira D.B. 1994. Doenças diagnosticadas pelo Laboratório Regional de Diagnósticos em 1993. Boletim do Laboratório Regional de Diagnóstico no.14, p.23-26.

Silva A.D., Spilki F.R., Franco A.C., Esteves P.A., Hübner S.O., Driemeier D., Oliveira A.P., Rijsewijk F. \& Roehe P.M. 2006. Vaccination with a gE-negative bovine herpesvirus type 1 vaccine confers insufficient protection to a bovine herpesvirus type 5 challenge. Vaccine 24: 3313-3320.

Silva A.M., Flores E.F., Weiblen R., Botton S.A., Irigoyen L.F., Rohe P.M., Brum M.C. \& Canto M.C. 1998. Infecção aguda e latente em ovinos inoculados com o herpesvírus bovino tipo 5 (BOHV-5). Pesq. Vet. Bras. 18:99-106.

Souza V.F., Melo S.V., Esteves P.A., Schmidt C.S.R., Gonçalves D., Schaefer R., Silva T.C., Almeida R.S., Vicentini F.K., Franco A.C., Oliveira E.A.S., Spilki F.R., Weiblen R., Flores E.F., Lemos R.A., Alfieri A.A., Pituco E.M. \& Roehe P. M. 2002. Monoclonal antibody characterization of bovine herpesviruses types 1 (BHV-1) and 5 (BOHV-5). Pesq. Vet. Bras. 22:13-18.

Tanwar R.K., Malik K.S. \& Sadana J.R. 1993. Polioencephalomalacia induced with amprolium in buffalo calves: pathologic changes of the central nervous system. J. Vet. Med., Series A, 40:58-66.

Vogel F.S., Caron L., Flores E.F, Weiblen R., Winkelmann E.R., Mayer S.V. \& Bastos R.G. 2003. Distribution of bovine herpesvirus type 5 DNA in the central nervous system of latently, experimentally infected calves. J. Clin. Microbiol. 41:4512-4520.

Watt J.A., Johonston W.S., Macleod N.S. \& Barlow R.M. 1981. Infectious bovine rhinotracheitis and encephalitis. Vet. Rec. 17:63-64.

Weiblen R., Barros C.S.L., Canabarro T.F. \& Flores E.F. 1989. Bovine meningoencephalitis from IBR virus. Vet. Rec. 124:666-667.

Wernery U., Hayden-Evans J. \& Kinne J. 1998. Amprolium induced cerebrocortical necrosis $(\mathrm{CCN})$ in dromedary racing camels. J. Vet. Med., Series B, 45:335-343. 